\title{
EFFECTS OF LAND AREA AND AGRICULTURAL INVESTMENT ON LABOR THROUGH GRDP DISTRICT / CITY OF EAST JAVA 2017
}

\author{
Achmad Daengs GS ${ }^{1}$, Mahjudin ${ }^{2}$, Eva Desembrianita ${ }^{3}$ \\ Universitas 45 Surabaya $^{1}$ \\ Universitas Muhammadiyah Gresik ${ }^{2,3}$ \\ Email Corespondensi : bumigora80@gmail.com
}

\begin{abstract}
The objectives of this study are to probe the effects of land area and agricultural investment on labor through district / city GRDP in East Java. This research uses explanatory type by a quantitative approach. Data collection techniques in this study are carried out by means of a literature study. Data analysis technique used is Structural Equation Model (SEM) with the Smart Partial Least Square (PLS) tool. The results in this study indicate that: (1) Land Area has a significant effect on district / city GRDP of East Java; (2) Agricultural Investment has a significant effect on district / city GRDP of East Java; (3) GRDP has a significant effect on District / City labors of East Java.
\end{abstract}

Keywords: Land Area, Agricultural Investment, GRDP, Labor

\section{INTRODUCE}

Indonesia is an agrarian country that has rich natural resources and plentiful labor, so that until now the agricultural sector is one of the priorities that gets the government attention. The agricultural sector has a multifunctionality that covers aspects of production or food security, improving the farmers welfare or alleviating poverty, and preserving the environment (Sudaryanto and Rusastra, 2006). Data from the Central Statistics Agency (BPS) in 2019 shows that the agricultural sector ranks fourth in the sector's contribution to GDP in 2018. This is because agriculture in terms of production is the second most influential sector after the manufacturing industry. Whereas when compared to other sectors agriculture is still in fourth position besides the trade and construction sector (BPS, 2019).

Agricultural sector in its production process requires the main production factor, namely land. According to Sumardjono (2008), land has special characteristics that are two-sided, namely as objects and as natural resources. Land becomes an object if it has been cultivated by humans, for example into agricultural land or can also be developed into urban land. Its development is carried out by the government through the provision of infrastructure. Provision of this infrastructure has an impact on increasing value of the land. Another characteristic of land is its permanent nature, limited amount, and its supply which cannot be changed.

Indonesia amount of land now compared to 10 years ago has narrowed. The amount of agricultural land in Indonesia is getting narrower because of the increasing population growth rate. This is not proportional to the food needs that continue to increase when compared to the available land, and therefore needs to be balanced with efforts to increase agricultural sector production with the maximization of available land through government programs. This also happened in East Java, which showed a high rate of depreciation of agricultural land in East Java, which averaged 2,900 hectares per year (Surya, 2019).

One of the efforts that can increase contribution in the agricultural sector to GRDP is absolutely needed investment. Assumed the importance of the agricultural sector development as a trigger for economic progress, it must be followed by a large investment in the agricultural sector, so that it will increase economic growth. In 
accordance with the World Food Security Summit held in November 2009 yielded a commitment to increase investment in the agricultural sector and eliminate hunger problems faster than originally targeted. The high poverty rate in developing countries as said by Todaro (2006) is due to the fact that most of the population works in the agricultural sector and has low productivity. Thus, investment in agriculture will be able to boosting technological innovations to increase the productivity of the agribusiness sector so as to be able to provide increased welfare to business people in particular, and to society in general.

Consistent with Sudirja (2008) the conversion of agricultural land functions is not merely having a negative impact such as reducing rice production, but it can also have a positive impact on the new jobs availability for a number of farmers, especially farm workers who are affected by the conversion of functions and increase economic growth. Datrini (2009) suggests that labor factor is an important factor in relation to an increase in a region's GRDP. According to him the rate of investment growth will determine the rate of growth of labor, then the growth of labor will determine the amount of output growth.

\begin{tabular}{l}
\hline LITERATURE REVIEW \\
\hline Land area \\
Land has a very important role for \\
human life, all forms of human intervention \\
are cyclical and permanent to meet the needs \\
of life, both material and spiritual originating \\
from land covered in terms of land use. \\
Various types of land use are found on the \\
surface of the earth, each type has its own \\
characteristics (Juhadi, 2007). Assis et al. \\
(2014) said that land area is the only factor \\
that has a significant effect on monthly \\
income for farmers, so if land area increases, \\
farmers' income will increase.
\end{tabular}

\section{Agricultural Investment}

Investment theory is the theory of capital demand. Investment is the flow of expenditure that increases the stock of physical expenditure or in other words investment is the amount spent by the business sector to increase the stock of capital in a certain period. Investment usually occupies a relatively small proportion of aggregate demand, but investment fluctuations occupy most of the business cycle movement in GDP. One reason why high-growth countries are because they devote a substantial share of output to investment (Makmun, 2003). Bank Indonesia and the Central Statistics Agency interpret investment as an investment activity in various economic activities in the hope of obtaining benefits in the future.

Increased economic growth shows the performance of the city development in East Java Province at the macro level has risen from crisis situation. (Achmad Daengs GS, et al. 2017 : 15).

\section{GRDP}

Gross Regional Domestic Product (GRDP) is the net value of final goods and services produced by various economic activities in a region in a period (Sasana, 2006). Therefore, the GRDP amount produced by each region is highly dependent on the potential of natural resources and factors of production in the area. The limitation in providing these factors causes the GRDP amount varies between regions. GRDP is the total aggregate of the amount of income obtained by citizens both inside and outside the country. Gross regional domestic product shows a country's ability to create an equitable distribution of income in every area of life (Sukirno, 2010). The benefits of the GRDP data are as follows (BPS, 2019):

1. Knowing or examining the economic structure or structure of a region.

2. Comparing the economy of a region from time to time.

3. Comparing economies between regions.

4. Formulate government policies.

The GDP can be periodically presented in two forms, namely on the basis of price valid and at constant prices in a year or quarter, as the following is explained (BPS, 2014):

1. Presentation at current prices, all 
aggregate income is valued at stated prices applies to each year, both when assessing production and costs between and in the valuation of value added components and expenditure components GRDP.

2. Presentation at constant prices for a base year, all aggregates income is valued at the price that occurs in the base year (in this case used constant prices based on prices in 2000). Because using fixed prices, the aggregate development from year to year is solely due by the real development of quantum production without containing fluctuations price.

\section{Labor}

Labor can also be interpreted, that labor is people who are willing or able to work for themselves or family members who do not receive wages and those who work for wages (Tambunan, 2001), whereas in the opinion of Simanjuntak in Tambunan (2001), labor is a group of people of working age, where they are able to work or carry out economic activities in producing goods and services to meet the needs of the community. Workers are residents of the working age who are ready to do work, including those who are already working, those who are looking for work, those who are in school and those who take care of the household.

Definition of labor according to Sumitro Djojohadikusumo is all people who are willing and able, and this group includes those who work for themselves, family members who do not receive payment and those who work to receive payment /wages/ salary (Djojohadikusumo, 2005). Meanwhile, according to Siamanjuntak in Manulang (2001) workers are residents who are already or are working, who are looking for work, and who carry out other activities such as attending school and taking care of the household. In practical terms, the definition of labor and not labor according to him is only distinguished by age limits

\section{Conceptual Framework}

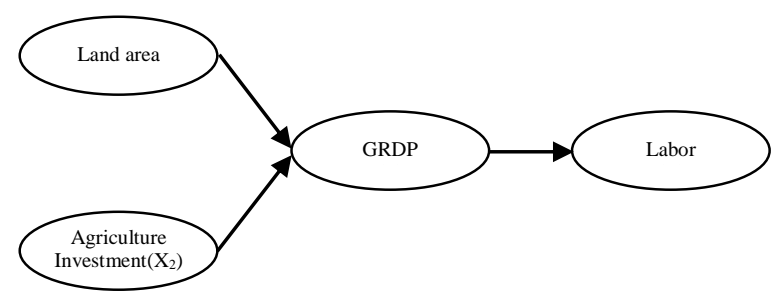

Figure 1. Conceptual Framework

\section{Hypothesis}

H1 : Land area has a significant effect on GRDP.

$\mathrm{H} 2$ : Agricultural investment has a significant effect on GRDP.

H3 : GRDP has a significant effect on labor.

RESEARCH METHOD
Types of research
The research method is a step
procedure that will be performed to collect
data in order to solve problems or test
hypotheses. According to Sugiyono (2016),
the research method is a scientific way to
obtain data with specific purposes and uses.
The research is a quantitative approach with
a causal associative method (cause and
effect) with. By using the research method
will be seen a significant relationship
between the variables studied.

According to Sugiyono (2016) quantitative methods are data in the form of numbers or qualitative data that is framed / scoring. Quantitative methods can be interpreted as research methods based on the philosophy of positivism, used to examine populations or specific samples, data collection using research instruments, quantitative / statistical data analysis, with the aim to test the hypotheses that have been set (Sugiyono, 2016).

\section{Definition of Variable Operations}

An operational definition is a definition given to a variable or construct by means of providing meaning or specifying an activity, or providing an operation needed to measure 
the construct or variable (Nazir, 2014). The following will describe the operational definition of each research variable as follows:

\section{Land Area (X1)}

Land area is the area of paddy fields that will be planted in certain seasons. Land area data in this study is the total area of District / City land in East Java expressed in hectares in 2017.

2. Agricultural Investment (X2)

Investment is an investment activity in various economic activities with the hope of obtaining profits. Agricultural investment data in this study are the investment value of District / City in East Java expressed in rupiah in 2017.

3. GRDP $(Z)$

GRDP is the total value added of goods and services produced from all economic activities in all regions in a certain year period which is generally within one year. GRDP data in this study is the value of District/ City GRDP in East Java expressed in rupiah in 2017.

4. Labor (Y)

Labor is everyone who is able to do work to produce goods and services. The workforce in this study is seen from the quality of the workforce as measured by the number of District / City workforce in East Java in 2017.

\section{Data collection technique}

Data collection techniques in this study were carried out by means of literature study, namely taking data collected from the literature or readings in the form of secondary data related to the problem to be discussed. The data collected is tabulated for further processing and analysis.

\section{Data analysis technique}

Analysis technique chosen to evaluate data and test the hypotheses in this study is The Structural Equation Model (SEM). To answer the hypothesis used Partial Least Square (PLS). According to Ghozali (2012) calculations are done using the Smart Partial Least Square (PLS) tool, because it is multi- path and the model used is Reflective. Calculation model is finished by using the Smart PLS tool because in this study it has a multi-path relationship and is formative and reflective.

\section{ANALYSIS AND DISCUSSION \\ Inner Model Evaluation \\ The inner model which is sometimes also called (inner relation, structural model and subtantive theory) specifies the effects among research variables (structural model). \\ Inner Model Test or Structural Model Test}

Analysis result of the suitability of the structural model constructed show the conclusion that the overall model has been "Relevant" to explain the variables studied and their effects on each variable. For endogenous latent variables in the structural model which has an $\mathrm{R}^{2}$ of 0.67 indicating that the model is "good", $\mathrm{R}^{2}$ of 0.33 indicates that the model is "moderate", $\mathrm{R}^{2}$ of 0.19 indicates that the model is "weak" (Ghozali, 2012). The PLS output as described below:

Table 1. R-Square value

\begin{tabular}{|c|c|}
\hline & $\boldsymbol{R}$-Square \\
\hline Land area $\left(\mathrm{X}_{1}\right)$ & \\
\hline $\begin{array}{c}\text { Agriculture Investment } \\
\left(\mathrm{X}_{2}\right)\end{array}$ & \\
\hline PDRB $(\mathrm{Z})$ & 0.120 \\
\hline Labor $(\mathrm{Y})$ & 0.091 \\
\hline
\end{tabular}

Results from the table above show that the Land Area and Agricultural Investment variables that affect the GRDP in the structural model have an R2 of 0.409 which indicates that the "Moderate" model. Then, the GRDP variable affecting Labor has an $\mathrm{R}^{2}$ of 0.269 which means the "Weak" model. The suitability of the structural model can be seen from Q2, as follows:

$$
\begin{aligned}
\mathrm{Q}^{2} & =1-\left[(1-\mathrm{R} 1)^{*}(1-\mathrm{R} 2)\right] \\
& =1-\left[(1-0,120)^{*}(1-0,091)\right] \\
& =1-[(0,880) *(0,909)] \\
& =1-[0,800] \\
& =0,200
\end{aligned}
$$


ACHMAD DAENGS GS ${ }^{1}$, MAHJUDIN ${ }^{2}$, EVA DESEMBRIANITA ${ }^{3}$

Effects of Land Area and Agricultural Investment on Labor Through Grdp District / City Of East Java 2017

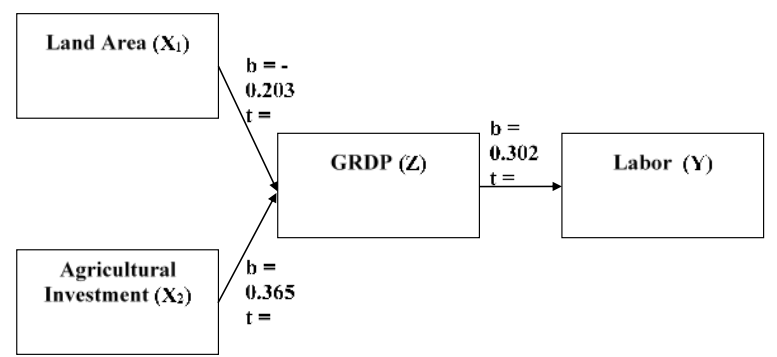

Figure 2. Inner PLS Model

There are exogenous variables within inner model under study, namely Land Area and Agricultural Investment, then the endogenous variable in the inner model under study is Labor while the intervening variable in the inner model under study is the GRDP. The results of the inner weight values in Figure 1 above indicate that the GRDP variable is affected by the Land Area and Agricultural Investment, then the Labor variable is affected by the GRDP shown in the following equation:

$$
\begin{aligned}
& Z=-0.203 X_{1}+0.365 X_{2} \\
& Y=0.302 Z
\end{aligned}
$$

\section{Hypothesis Testing Results Hypothesis 1 Test (H1)}

First hypothesis in the study does not proven to be true, this is known from the tvalue of 0.818 which means it is smaller than 1.96, this means that the Land Area has no significant effect on the GRDP. Direction of the connection between two variables is negative, which means that the higher the land area, the lower the GRDP but will not be significant by having a large influence of 0.203 .

\section{Hypothesis 2 (H2)}

Second hypothesis in the study proved to be true, this is known from the t-value of 2,648 which means it is greater than 1.96 , this means that Agricultural Investment has a significant effect on GRDP. Direction of the connection between two variables is positive which means there is a direct connection so that it can be interpreted that the higher the Agricultural Investment will be able to increase the GRDP by having a large effect that is 0.365 .

\section{Hypothesis 3 (H3)}

Third hypothesis of the study proved its truth, this is known from the t value of 3.304 which means greater than 1.96 , this means that the GRDP has a significant effect on labor. The direction of the connection between the two variables is positive which means there is a direct connection so that it can be interpreted that the higher the GRDP will also increasingly have an impact on increasing the workforce by having a large influence of 0.302 .

\begin{tabular}{c} 
DISCUSSION \\
\hline Effect of Land
\end{tabular}

\section{Effect of Land Area on GRDP}

The results of data analysis showed that the area of land does not have a significant effect on the GRDP of District / City of East Java as evidenced by the $t$ value of 0.818 , which means it was smaller than 1.96 , so it can be explained that the increase in economic growth in East Java that was stated in the GRDP had not certainly can be increased through an increase in land area. The influence of land area on District / City GRDP of East Java is negative which indicates that the increasing land area will significantly reduce District / City GRDP of East Java. Thus the first hypothesis in this study which reads "Land area significantly affect the GRDP", can be declared acceptable.

The findings of this study prove that the land area does not have a significant and negative effect on the GRDP of District / City of East Java. The outcome in this study are not in line with the results that conducted by Arotaa et al (2016) which proves that there is a connection between the area of agricultural land with the gross regional domestic product of the agricultural sector, when the area of land increases or decreases the gross regional domestic product continues to increase.

\section{Effect of Agricultural Investment on GRDP}

Results from data analysis carried out show that agricultural investment has a significant effect on GRDP in District / City 
of East Java as evidenced from the $t$ value of 2,648 which means greater than 1.96 , so it can be explained that the District/ City GRDP in East Java can be formed through agricultural investment. The effect of agricultural investment on GRDP is positive which shows that the higher agricultural investment budgeted by the government will be able to increase agricultural investment in districts / cities in East Java. Thus the second hypothesis in this study which reads "Agricultural investment has a significant effect on GRDP", can be declared acceptable.

The findings in this study prove that agricultural investment has a significant and positive effect on GRDP. This can be interpreted that the investment in capital has an important role in increasing the GRDP in regencies / cities in East Java. In other words, GRDP in District / City in East Java can be increased through high agricultural investment. Therefore, if the Government of East Java wants to increase its GRDP, it is necessary for the government to pay attention to the level of investment spent by the domestic and foreign governments in the agricultural sector. These results are in line with the findings of research conducted by Faiziah and Sofyan (2014) where in their research it was proven that there is a positive influence between investment in the sector and GRDP in the agricultural sector.

\section{Effect of GRDP on Labor}

Data analysis result showed that the GRDP had a significant effect on the District/ City Labor of East Java as verified by t-value of 3,304, which means it was greater than 1.96 , so it can be explained that a high workforce could be formed through the high GRDP. Thus the third hypothesis in this study which reads "GRDP has a significant effect on labor", can be declared acceptable.

The findings in this study prove that the GRDP significantly affect the District/ City Labor of East Java positively. This positive influence can be interpreted that the GRDP has a role in increasing the number of District/ City labor in East Java. Therefore, if the East Java government wants to increase its workforce, it is very important for the government to pay attention to the level of Distric / City GRDP in East Java.

Economic development in addition to raising the per capita income also increasaed life expectancy, literacy, health and public education. (Achmad Daengs GS, et al. 2014 : $60)$.

\section{CONCLUSION}

1. Land area has a significant effect on District / City GRDP in East Java. Thus the first hypothesis in this study is declared acceptable.

2. Agricultural Investment has a significant influence on District / City GRDP in East Java. Thus the second hypothe.ppolllsis in this study is declared acceptable.

3. GRDP has a significant influence on District / City Workers in East Java. Thus the third hypothesis in this study is declared acceptable.

\section{REFERENCES}

Assis, K., Nurrul Azzah, Z \& Mohammad Amizi. 2014. "Relationship Between Socioeconomic Factors, Income And Productivity Of Farmers: A Case Study On Pineapple Farmers". International Journal of Research in Humanities, Arts and Literature. 1(2). Pp 67-78.

Datrini. 2009. Dampak Investasi dan Tenaga Kerja Terhadap Pertumbuhan Ekonomi Serta Pengaruhnya Terhadap Tingkat Kemiskinan di Provinsi Bali. Jurnal.

Djojohadikusumo, S. 2005. Ekonomi Pembangunan, Jakarta: Pustaka Ekonomi.

Gatot Soeherman, Achmad Daengs, Mursinto, Djoko, Ratnawati, Tri, 2014. The Influential Of Private Investment, Public Investment On Economic Growth and Labor Absorption And Public Welfare Of District / City In East Java Province. GSTF Journal Of Business Review (GBR) Vol. 3 No. 4. Page : 45-62.

Ghozali, I. 2012. Aplikasi Analisis Multivariate dengan Program IBM 
ACHMAD DAENGS GS ${ }^{1}$, MAHJUDIN ${ }^{2}$, EVA DESEMBRIANITA ${ }^{3}$

Effects of Land Area and Agricultural Investment on Labor Through Grdp District / City

Of East Java 2017

SPSS. Yogyakarta: Universitas Diponegoro.

Juhadi. 2007. "Pola Pemanfaatan Lahan dan Degradasi Lingkungan pada Kawasan Perbukitan". Jurnal Geografi Volume 4 No 1 Januari 2007, 11-12.

Mahjudin, Daengs, Achmad, 2017. Influential Of Economic Growth, Manpower Absorption Public Werlfare. Jurnal Ekonomi dan Bisnis OPTIMUM Vol. 7 No. 1, Fakultas Ekonomi Universitas Ahmad Dahlan Yogyakarta, page : 14-26.

Makmun, dan Akhmad Y. 2003. "Pengaruh Investasi dan tenaga Kerja Terhadap PDB Sektor Pertanian". Kajian Ekonomi dan Keuangan, Vol. 7 No.3 September.

Marihot, Manullang. 2001. Manajemen Sumber Daya Manusia. Yogyakarta: BPFE.

Nazir, Moh. 2014. Metode Penelitian. Bogor: Ghalia Indonesia.

Sasana, H. 2006. "Analisis Dampak Desentralisasi Fiskal Terhadap Pertumbuhan Ekonomi di Kabupaten/Kota Provinsi Jawa Tengah", Dinamika Pembangunan, Vol. 3, No. 2, hal.145-170.

Sudaryanto, T. dan Rusastra, I.W. 2006. "Kebijakan strategis usaha pertanian dalam rangka peningkatan produksi dan pengentasan kemiskinan". Jurnal Litbang Pertanian, 25 (4).

Sudirja, R. 2008. Mewujudkan Kedaulatan Pangan Melalui Kebijakan Pengelolaan Lahan Pertanian Pangan. Disampaikan pada Seminar Regional Musyawarah Kerja Badan Eksekutif Himpunan. Mahasiswa Ilmu Tanah Indonesia Wilayah II, Gedung Student Centre Faperta Unpad-Jatinangor, 29 Januari 2008. Bandung.

Sugiyono. 2016. Metode Penelitian Kuantitatif, Kualitatif dan $R \& D$. Bandung: PT Alfabeta.

Sukirno, S. 2010. Makroekonomi. Teori Pengantar. Edisi Ketiga. Jakarta: PT. Raja Grasindo Perseda.
Sumarjono, Maria SW. 2006. Kebijakan Pertanahan, Antara Regulasi dan Implementasi -Edisi revisi. Jakarta: Penerbit Buku Kompas.

Surya. 2019. Penyusutan Lahan Pertanian di Jatim Tinggi, Khofifah Larang Alih Fungsi Lahan Pertanian,

https://surabaya.tribunnews.com/2019/11/19 /penyusutan-lahan-pertanian-di-jatimtinggi-khofifah-larang-alih-fungsilahan-pertanian, diakses tanggal 28 Desember 2019.

Todaro, Michael P. dan Stephen C. Smith. 2006. Pembangunan Ekonomi (edisi kesembilan, jilid I). Jakarta: Erlangga.

Tulus H. Tambunan. 2001. Perekonomian Indonesia. Jakarta: Penerbit Ghalia. 